\title{
Comparative Study between Oral Zinc Sulphate versus Electrocautery in Treatment of Patients with Recurrent Warts \\ Mohamed Abdel Moneim Abdel Aal ${ }^{1}$, Hamed Mohamed Abdo ${ }^{1}$, Mohamed Abdel Latif Hasheesh ${ }^{2}$, Mohamed Masoud Abdel Gayed ${ }^{1 *}$ \\ Departments of ${ }^{1}$ Venereology and Anrology and ${ }^{2}$ Clinical Pathology, Faculty of Medicine, Al-Azhar University, Cairo, Egypt
}

*Correspondence author: Mohamed Masoud Abdel Gayed, Mobile: (+20)01156808000, E-mail: ebn.masoud2020@gmail.com

\begin{abstract}
Background: viral warts are benign proliferations of the skin and mucosa that are caused by HPV infection. They consider common and major health problem. Zinc can be a therapeutic option by medulating the immune system in patients with viral warts.

Objective: the aim of this work was to compare the effect of oral zinc sulfate versus electrocautery in treatment of patients with recurrent warts.

Patients and Methods: this study was carried on 90 patients with common warts. The patients were divided into three groups (A, B, C) of 30 patients. Group A consisted of 30 patients treated with oral zinc sulfate, 30 patients in group $\mathrm{B}$ treated by electrocautery while group $\mathrm{C}$ was given placebo in the form of starch capsules.

Results: our results showed more improvement in group of electrocautery than in the group of zinc sulphate, and showed increase in complications in electrocautery group with statistically significant difference. In this study there was a positive correlation between percentage of improvement and serum level of zinc with a significance increase in the serum zinc level before and after treatment in zinc sulphate group.

Conclusion: this study showed that the role of oral zinc sulphate as a systemic treatment modality for common warts could have the advantage of being non-invasive, non scarring and with minimal side effects, but it was not very effective so it can be taken with other modalities of treatment and not as monotherapy.

Keywords: Oral Zinc Sulphate versus Electrocautery, HPV, Warts
\end{abstract}

\section{INTRODUCTION}

Warts are benign proliferations of skin and mucosa that results from infection with human papilloma viruses (HPVs) ${ }^{(1)}$. HPVs are members of genus family papovaviruses, which are small double stranded DNA viruses that replicate inside the nucleus (2).

Warts are one of the most common diseases seen in the dermatology clinics. The role of immune system in determining the outcome of HPV infection is well documented ${ }^{(3)}$.

Adequate intake of zinc is required for any rapidly dividing cell particularly those of the immune system to function efficiently, and its deficiency compromises the function of immune cells, especially $\mathrm{T}$ cell function. Zinc deficiency leads to a decreased number of $\mathrm{T}$ cells and disruption of their function, including a shift of the T-helper (Th1) cell response to Th2 2 predominance ${ }^{(4)}$.

Zinc also results in reduced killing activity in natural killer (NK) cells ${ }^{(5)}$. Neutrophil count is reduced and their recruitment is diminished during zinc deficiency ${ }^{(6)}$.

Zinc sulphate has been used orally and topically and also intralesionally for the treatment of warts in some clinical trials with favorable results considering the role of zinc in immune function and the efficacy of zinc sulphate in wart resolution, estimation of zinc level in patients with warts might be of value ${ }^{(7)}$.

Destructive therapy targets to damage or remove lesion, rather than aiming to eradicate the pathogen. The options range from surgical excision, cautery, curettage, cryotherapy to laser application ${ }^{(8)}$.

An electric current can deliver quite a lot of heat energy and it is this heat which used to remove warts in electrosurgery. A metal probe with a current is applied to the warts with effectively burns it off, heat has powerful effect on living tissues, drying them out and denaturing important proteins and other structures to kill of unwanted cells. Because of this mechanism, it is an extremely effective method with warts ${ }^{(9)}$.

\section{AIM OF THE WORK}

The aim of this work is to compare the effect of oral zinc sulfate versus electrocautery in treatment of patients with recurrent warts.

\section{PATIENTS AND METHODS}

This study was conducted on 90 patients with common warts. The patients were collected from the Out-patient Clinics of Dermatology and Venereology Department, Kafr El-Dawar Hospital.

\section{Inclusion criteria}

Patients suitable for participation were:

1. Individuals with common warts with a history of recurrence.

2. Individuals of both sexes.

\section{Exclusion criteria}

1. Subjects with acute infections or systemic diseases.

2. Patients on any immunomodulutatony medications or with immunosuppressive disease. 
3. Patients with compromised wound healing, DM, peripheral neuropathy and peripheral arterial or venous disease.

4. Pregnancy and lactation.

5. Patients who had absolute contraindication for local anesthesia.

\section{Ethical considerations}

The study was approved by the Ethics Board of Al-Azhar University.A written informed consent from every patient was obtained before procedure. Every participant had a code number. Photos were taken to the diseased part only. All the records were confidential.

\section{Methods}

The patients were divided into three groups (A, B,

C) of 30 patients:

- Group A : was treated by oral zinc sulfate.

- Group B : was treated by electrocautery.

- Group C: was given a placebo in the form of starch capsules.

\section{All patients were subjected to:}

1. Complete history taking.

2. Thorough general and dermatological clinical examinations.

3. Clinical assessment of warts including: number, location, duration of the disease, types and duration of previous treatments.

4. Collection of venous blood sample for measurement of serum zinc level before and after treatment for patients of group A and group C.

- Sample volume: $4 \mathrm{ml}$ of whole blood.

- Method of blood sampling: venipuncture method.

- Type of tube: Z-serum clot activator $13 \times 75$ Vacuette tube, Manufactured by Greiner bio-one $\mathrm{GmbH}$, Made in Austria.

- Type of sample processed: serum.

- Device: Modular Hitachi-Roche ${ }^{\circledR}$; full automated analytical device.

5. The percent of improvement of the cases was classified into excellent $>75 \%$, moderate $<75-50 \%$, mild $<50 \%$ and no change.

\section{Therapy:}

- Group A: patients were treated by oral zinc sulfate at a dose of $\mathbf{1 0} \mathbf{m g} / \mathbf{K g} / \mathbf{d a y}$ for 12 weeks.

- Group B: patients were treated by electrocautery. The warts and the area around it was cleaned by antiseptic; Then local anesthesia (Lidocaine $\mathrm{Hcl} 2 \%, 20 \mathrm{mg} / \mathrm{ml}$ ) was injected subcutanously and electrocautery was done.

- Group C: patients were given a placebo in the form of starch capsules.

\section{Follow up:}

1. The duration of the study was six months. The patients were followed up during and 12 weeks after the end of the last treatment to asses any recurrence or side effects.

2. Photographs were taken before starting therapy and at every visit (monthly) and at the end of therapy.

\section{Statistical analysis:}

Statistical analysis was carried out using SPSS statistics software version 23. Quantitative data were tested for normality using KolmogorovSmirnov test. The studied variables were normally distributed, so they were described by mean, and standard deviation. Qualitative data was expressed by numbers and percent.

The following are used in statistical analysis:

1. Arithmetic mean (X).

2. Standard deviation (S.D).

3. Chi-square (X2).

4. One way: Analysis of Variance (ANOVA).

The probability "P value $\leq 0.05$ "

\section{RESULTS}

Group A consisted of 30 patients treated with oral zinc sulfate, 30 patients in group B treated by electro cautery while group $\mathrm{C}$ was given a placebo in the form of starch capsules.

There was no statistical significance difference $(\mathrm{p}=.186)$ between the three groups according to demographic characteristics as illustrated in table 1.

Table (1): Comparison between the three groups according to demographic characteristics

\begin{tabular}{|c|c|c|c|c|c|c|c|}
\hline \multirow[b]{2}{*}{ Gender } & \multicolumn{2}{|c|}{ Group A $(\mathbf{N}=\mathbf{3 0})$} & \multicolumn{2}{|c|}{ Group B $(N=30)$} & \multicolumn{2}{|c|}{ Group C $(\mathrm{N}=30)$} & Test of significance (p) \\
\hline & No. & $\%$ & No. & $\%$ & No. & $\%$ & \multirow{4}{*}{ P (2) } \\
\hline Male & 17 & 56.7 & 16 & 53.3 & 14 & 46.7 & \\
\hline Female & 13 & 43.3 & 14 & 46.7 & 16 & 53.3 & \\
\hline $\begin{array}{c}\text { Age/(years) } \\
\text { Mean } \pm \text { SD }\end{array}$ & \multicolumn{2}{|c|}{$31.8 \pm 15.4$} & \multicolumn{2}{|c|}{$28.6 \pm 11.7$} & \multicolumn{2}{|c|}{$25.3 \pm 12.9$} & \\
\hline
\end{tabular}

There was no statistical significance difference $(\mathrm{p}=.511)$ between the three groups as regards duration of disease as illustrated in table 2. 
Table (2): Comparison between three groups according to duration of disease

\begin{tabular}{|c|c|c|c|c|}
\hline & $\begin{array}{c}\text { Group A } \\
(\mathbf{N}=30)\end{array}$ & $\begin{array}{c}\text { Group B } \\
(\mathbf{N}=30)\end{array}$ & $\begin{array}{c}\text { Group C } \\
(\mathbf{N}=30)\end{array}$ & $\begin{array}{c}\text { Test of significance } \\
(\mathbf{p})\end{array}$ \\
\hline $\begin{array}{c}\text { Duration of disease (months) } \\
\text { Mean } \pm \text { SD }\end{array}$ & $10.5 \pm 5.6$ & $9.6 \pm 4.9$ & $11.6 \pm 8.3$ & $(\mathbf{p = . 5 1 1 )}$ \\
\hline
\end{tabular}

There was no statistical significance difference between the three groups as regards number of warts $(\mathrm{P}=$ .382), as illustrated in table 2 .

Table (3): Comparison between the three groups according to number of warts

\begin{tabular}{|c|c|c|c|c|c|c|c|}
\hline \multirow{2}{*}{ No. of warts } & \multicolumn{2}{|c|}{$\begin{array}{c}\text { Group A } \\
(\mathbf{N = 3 0})\end{array}$} & \multicolumn{2}{c|}{$\begin{array}{c}\text { Group B } \\
(\mathbf{N = 3 0}\end{array}$} & \multicolumn{2}{c|}{$\begin{array}{c}\text { Group C } \\
(\mathbf{N}=\mathbf{3 0})\end{array}$} & $\begin{array}{c}\text { Test of significance } \\
(\mathbf{p})\end{array}$ \\
\cline { 2 - 7 } & $\mathbf{N o .}$ & $\mathbf{\%}$ & $\mathbf{N o .}$ & $\mathbf{\%}$ & $\mathbf{N o .}$ & $\mathbf{\%}$ & \multirow{2}{*}{$(\mathbf{P}=\mathbf{. 3 8 2})$} \\
\hline $\mathbf{( 1 - 3 )}$ & 9 & 30 & 12 & 40 & 8 & 26.7 & \\
\hline $\mathbf{( 4 - 6 )}$ & 8 & 26.7 & 12 & 40 & 8 & 26.7 & \\
\hline$>\mathbf{6}$ & 13 & 43.3 & 6 & 20 & 14 & 46.6 & \\
\hline Total & 30 & 100 & 30 & 0 & 30 & 100 & \\
\hline
\end{tabular}

There was no statistical significance difference ( $\mathrm{p}$ value $>.05$ ) between the three groups as regards site of warts as illustrated in table 4.

Table (4): Comparison between the three groups according to site of warts

\begin{tabular}{|c|c|c|c|c|c|c|c|}
\hline \multirow[t]{2}{*}{ Site of warts } & \multicolumn{2}{|c|}{$\begin{array}{c}\text { Group A } \\
(\mathbf{N}=\mathbf{3 0})\end{array}$} & \multicolumn{2}{|c|}{$\begin{array}{c}\text { Group B } \\
(\mathbf{N}=\mathbf{3 0})\end{array}$} & \multicolumn{2}{|c|}{$\begin{array}{c}\text { Group C } \\
(\mathbf{N}=\mathbf{3 0})\end{array}$} & Test of significance (p) \\
\hline & No. & $\%$ & No. & $\%$ & No. & $\%$ & \multirow{4}{*}{$(P=.930)$} \\
\hline Head\& Neck & 5 & 16.7 & 6 & 20 & 6 & 20 & \\
\hline Limbs & 25 & 83.3 & 24 & 80 & 24 & 80 & \\
\hline Total & 30 & 100 & 30 & 100 & 30 & 100 & \\
\hline
\end{tabular}

There was statistical significance difference $(\mathrm{p}=.002)$ between the three groups as regards percent of improvement as illustrated in table 5.

Table (5): Comparison between the three groups according to percent of improvement

\begin{tabular}{|c|c|c|c|c|c|c|c|}
\hline \multirow[t]{2}{*}{ Percent of improvement } & \multicolumn{2}{|c|}{$\begin{array}{c}\text { Group A } \\
(\mathbf{N}=\mathbf{3 0})\end{array}$} & \multicolumn{2}{|c|}{$\begin{array}{c}\text { Group B } \\
(\mathbf{N}=\mathbf{3 0})\end{array}$} & \multicolumn{2}{|c|}{$\begin{array}{c}\text { Group C } \\
(\mathbf{N}=\mathbf{3 0})\end{array}$} & $\begin{array}{l}\text { Test of significance } \\
\text { (p) }\end{array}$ \\
\hline & No. & $\%$ & No. & $\%$ & No. & $\%$ & \multirow{6}{*}{$(\mathbf{P}=.002 *)$} \\
\hline No change & 11 & 36.7 & 8 & 26.7 & 27 & 90 & \\
\hline Mild & 7 & 23.3 & 0 & 0 & 3 & 10 & \\
\hline Moderate & 5 & 16.7 & 0 & 0 & 0 & 0 & \\
\hline Excellent & 7 & 23.3 & 22 & 73.3 & 0 & 0 & \\
\hline Total & 30 & 100 & 30 & 100 & 30 & 100 & \\
\hline
\end{tabular}

*: statistically significant

\# p1 significance between group A and group B $=.0002^{*}, \mathrm{P} 2$ : significance between group B and group $\mathrm{C}=.0001 *$, p3: significance between group A and group $\mathrm{C}=.0001^{*}$

There was statistical significance difference $\left(\mathrm{p}<.0001^{*}\right)$ between the three groups as regards side effect and complications as group B recorded highest percentage in side effects scarring and recurrence in 8 cases ; 26.7\% while groups $\mathrm{A}$ and $\mathrm{C}$ showed no side effects detected as illustrated in table 6.

Table (6): Comparison between the three groups according to side effects and complications

\begin{tabular}{|c|c|c|c|c|c|c|c|}
\hline \multirow{2}{*}{ Scarring and recurrence } & \multicolumn{2}{|c|}{$\begin{array}{c}\text { Group A } \\
(\mathbf{N}=\mathbf{3 0})\end{array}$} & \multicolumn{2}{c|}{$\begin{array}{c}\text { Group B } \\
(\mathbf{N}=\mathbf{3 0})\end{array}$} & \multicolumn{2}{c|}{$\begin{array}{c}\text { Group C } \\
(\mathbf{N}=\mathbf{3 0})\end{array}$} & $\begin{array}{c}\text { Test of significance } \\
(\mathbf{p})\end{array}$ \\
\cline { 2 - 7 } & No. & $\boldsymbol{\%}$ & No. & $\boldsymbol{\%}$ & No. & $\boldsymbol{\%}$ & \multirow{2}{*}{$(\mathbf{P}<.0001 *)$} \\
\hline Positive & 0 & 0 & 8 & 26.7 & 0 & 0 & \\
\hline Negative & 30 & 100 & 22 & 73.3 & 30 & 100 & \\
\hline
\end{tabular}

*: statistically significant.

\# p1 significance between group A and group B $=.007^{*}, \mathrm{P} 2$ : significance between group B and group C $=.007^{*}, \mathrm{p} 3$ : significance between group A and group $\mathrm{C}=.9$ 
There was positive significant correlation $(\mathrm{p}<.001)$ between percent of improvement and serum zinc level as illustrated in table 7.

Table (7): Correlation between percent of improvement and serum zinc level

\begin{tabular}{|c|c|c|c|}
\hline \multicolumn{2}{|c|}{ Group A } & $\begin{array}{c}\text { Percent of } \\
\text { improvement }\end{array}$ & $\begin{array}{c}\text { Serum zinc level } \\
(\boldsymbol{\mu g} / \mathbf{d})(\mathbf{N}=\mathbf{3 0})\end{array}$ \\
\hline $\begin{array}{c}\text { Percent of } \\
\text { Improvement }\end{array}$ & Spearmen Correlation (r) & 1 & .586 \\
\cline { 2 - 4 } & $\mathrm{P}$ & & $.001^{*}$ \\
\hline
\end{tabular}

*: statistically significant

There was significant difference $(\mathrm{p}<.0001)$ in serum zinc level before and after treatment in group A, while there was no significant difference $(\mathrm{P}=.008)$ in serum zinc level before and after treatment in group $\mathrm{C}$ as illustrated in table 8 .

Table (8): Comparison between groups $\mathrm{A}$ and $\mathrm{C}$ according to serum zinc level before and after treatment

\begin{tabular}{|c|c|c|c|}
\hline & $\begin{array}{c}\text { Serum zinc level before } \\
\text { treatment } \\
(\boldsymbol{\mu} \mathbf{g} / \mathbf{d l})\end{array}$ & $\begin{array}{c}\text { Serum zinc level after } \\
\text { treatment } \\
(\boldsymbol{\mu} \mathbf{~ g} / \mathbf{d l})\end{array}$ & $\begin{array}{c}\text { Test of significance } \\
(\mathbf{p})\end{array}$ \\
\hline $\begin{array}{c}\text { Group A }(\mathbf{N}=\mathbf{3 0}) \\
\text { Mean } \pm \text { SD }\end{array}$ & $77.01 \pm 24.9$ & $103.9 \pm 23.2$ & $(\mathbf{P}<.0001 *)$ \\
\hline $\begin{array}{c}\text { Group C (N=30) } \\
\text { Mean } \pm \text { SD }\end{array}$ & $77.01 \pm 24.9$ & $76.01 \pm 24.5$ & $(\mathbf{P = . 0 8 )}$ \\
\hline
\end{tabular}

*: statistically significant

\section{DISCUSSION}

Our results showed no statistical significance difference between the groups of the study regarding age and sex.

In our study we found no statistical significance difference between groups of the study regarding to the duration of disease, number and sites of warts.

Witchey et al. ${ }^{(10)}$ found in their study that there was no significant difference between group A patients were given oral zinc sulphate and group B who received gluocose tablets as placebo regarding age, gender and number of warts which was in agreement with our study.

Abd El-Raheem et al. ${ }^{(11)}$ found in their study that there was no significant difference between the group who received oral zinc sulphate and the group who received oral placebo regarding to age, gender, duration of the disease and number of warts which run in line with the result of our results.

Our results showed significant improvement in the group of electrocautery than zine sulphate group and both groups showed significant improvement than placebo group.

In agreement with our study Mariane et al. ${ }^{(12)}$ observed that there was significant difference in the proportion of clinical response between their two studied groups. The group treated with zinc sulphate had proportion of complete response significantly higher than the placebo group.

In agreement with our study Khalifa et al. ${ }^{(13)}$ found that, zinc sulphate has been used successfully in the treatment of common warts and genital warts orally, and intraelsionally in recalcitrant common warts.
García et al. ${ }^{(14)}$ found in their study that there was no significant difference in the percentage of improvement between the use of oral zinc sulphate and the placebo group which was conflicting with the results of our study.

In disagreement with our study Moubasher et al. ${ }^{(15)}$ they showed that, there were no statistical significant differences between group that received Zinc and placebo group regarding treatment of warts.

Our results showed no significant correlation between percent of improvement in groups of electrocautery and zinc sulphate regarding age, duration of disease, site and number of warts.

Moniem et al. ${ }^{(16)}$ showed in their study that there was no statistical significant differences regarding age and number of warts in relation to percent of improvement between group I ( took oral zinc sulfate for one month ) and group II (placebo group) which was in agreement with our results. On the other hand, short duration of the disease was associated with better response on the percent of improvement in group I.

Our study found that there was a significant increase in the improvement percentage with increase in the serum level of zinc. Moniem et al. ${ }^{(16)}$ showed in their study that the serum level of zinc was significantly increased in the percentage of improvement in group I "treated by oral zinc sulphate" than in group II "placebo group" which was in agreement with our results.

There was significance increase in the serum zinc level before and after treatment in zinc sulphate group while there was no significance change in the serum zinc in the placebo group before and after treatment. Moniem et al. ${ }^{(16)}$ showed in their study that the serum 
level of zinc was significantly increased after therapy compared with that before treatment in group I "treated by oral zinc sulphate" than in group II "placebo group" which was in agreement with our results.

Regarding side effects only mild epigastric pain $(6 \%)$ was observed in our patients who did not require interruption of treatment. On the other hand in a study by Stefani $\boldsymbol{e t} \boldsymbol{a l} .{ }^{(17)}$ adverse effects reported by the patients treated with zinc sulfate were nausea, vomiting and diarrhea.

\section{CONCLUSION}

This study showed that the role of oral zinc sulphate as a systemic treatment modality for common warts could have the advantage of being non-invasive, non scarring and with minimal side effects, but it was not very effective so it can be taken with other modalities of treatment and not as monotherapy.

\section{RECOMMENDATIONS}

Further studies are needed for evaluation of the effectiveness of oral zinc sulphate in the treatment of different types of warts and to study the effect of topical zinc sulphate in treatment of warts.

\section{REFERENCES}

1. Lowg DR, Androphy EJ, Freedberg IM et al. (1999): Warts. In: "Dematology in General Medicine, Fitzpatrik TB", 5th ed., New York: McGrow-Hill Co., Chapt 244, Pp. 2484-97.

2. Odom RB, James WD and Berger TG (2006): Warts. In: "Andrew's Diseases of Skin, Clinical Dermatology", 10th ed., Philadelphia: W.B Saunders, Pp. 403-9.

3. Tindle RW and Frazer IH (1994): Immune response to human papillomaviruses and the prospects for human papillomavirus-specific immunization. Curr Top Microbial Immunol., 186: 217-53.

4. Wellinghusen $N$ and Kirchner $H$ (1997): The immunobiology of zinc. Immunol Today, 18: 519-21.

5. Ibs KH and Rink L (2003): Zinc altered immune function. J Nutr., 133: 1452-6.
6. Rink L and Haase $H$ (2007): Zinc homeostasis and immunity. Trends Immunol., 28: 1-4.

7. Sharquie KE, Khorsheed AA, Al-Nuaimy AA (2007): Topical zinc sulphate solution for treatment of viral warts. Saudi Med J., 287: 1418-21.

8. Al-Gurairi FT, Al-Waiz $M$ and Sharquie KE (2002): Oral zinc sulphate in the treatment of recalcitrant viral warts: randomized placebo-controlled trial. Br Dermatol., 146: 423-31.

9. Mun JH, Kim SH, Jung DS et al. (2011): Oral zinc sulfate treatment for viral warts: an open-label study. J Dermatol., 38: 541-545.

10. Witchey DJ, Witchey NB, Kauffman MMR et al. (2018): Plantar Warts: Epidemiology, pathophysiology and clinical management. J Am Osteop Assoc., 118(2): 92-105.

11. Abd El-Raheem TA, El-Shafie SM, Nassar MA et al. (2018): Comparative Study between Oral Zinc Sulphate, Amino Acids Chelated Zinc and Placebo in Treatment of Viral Warts. Egypt J Hosp Med., 71(4): 3039-3048.

12. Mariane S, Giuliana B, Elisa F et al. (2009): Efficacy comparison between cimetidine and zinc sulphate in the treatment of multiple and recalcitrant warts. An Bras Dermatol., 84: 23-9.

13. Khalifa ES, Alaa AK and Adil N (2007): Topical zinc sulphate solution for treatment of viral warts. Saudi Medical Journal, 28(9):1418-21.

14. García LDR, Flores GM, Mendoza AAY et al. (2009): Oral zinc sulfate for unresponsive cutaneous viral warts: too good to be true? A double-blind, randomized, placebocontrolled trial. Clin Exp Dermatol., 34: e984-e985.

15. Moubasher AEA, Hassan OM, Youssef EMK et al. (2016): Intralesional injection of purified protein derivatives versus zinc sulfate $2 \%$ in recalcitrant palmar and/or plantar warts. J Egypt Women Dermatol Soc., 13: 151-158.

16. Moniem EA, Genedy RM and Moussa R (2016): Oral zinc sulfate in the treatment of recalcitrant warts. Egypt $\mathbf{J}$ Dermatol Venerol., 36:34-8

17.Stefani M, Bottino G, Fontenelle E et al. (2009): Efficacy and comparison between cimetidine and zinc sulphate in the treatment of multiple and recalcitrant warts. An Bras Dermatol., 84: 23-9. 